\title{
A comparison between some wood bark extracts: Antifungal activity
}

\author{
Özlem ÖZGENÇ ${ }^{1 *}$, Sefa DURMAZ², Ümit Cafer YILDIZ1 ${ }^{1}$ Emir ERIŞIR ${ }^{3}$
}

\author{
${ }^{1}$ Karadeniz Technical University, Department of Forest Industry Engineering, Trabzon, TURKEY \\ ${ }^{2}$ Muğla Sitkı Koçman University, Kavaklıdere Vocational School, Department of Forestry and Forest \\ Products, Muğla, TURKEY \\ ${ }^{3}$ Karadeniz Technical University, Department of Pulp and Paper Technology, Trabzon, TURKEY \\ *Corresponding author: oozgenc@ktu.edu.tr
}

\section{Abstract}

Aim of study: The need for eco-friendly and bio-soluble wood preservatives has increased recently. In this study, antifungal effects of tree barks were researched.

Area of study: The maritime (Pinus pinaster L.), iron (Casuarina equisetifolia L.), mimosa (Acacia mollissima L.), calabrian pine (Pinus brutia Ten.), and fir (Abies nordmanniana) tree barks were used.

Material and Methods: The the solution at two concentrations was prepared to the substance obtained with alcohol benzene extraction method from the tree bark according to TAPPI standard. The effectiveness of bark extracts was evaluated against brown-rot fungus; Coniophera puteana, and white-rot fungus; Trametes versicolor.

Main results: This study indicates that tree bark extracts have potential to use as wood preservatives. Maritime pine and fir tree barks showed good resistance against T. versicolor more than C. puteana. On the contrary, iron and mimosa tree barks were more resistance against brown-rot fungus, C. puteana. Concentration is the most important factor for inhibition of fungal activity. Inhibition of fungal growth increased parallel with concentration.

Research highlights: It is thought that the rich structure of the bark extract in terms of natural phenolic compounds could inhibit fungal activity. This study indicates that tree bark extracts have potential to use as wood preservatives.

Keywords: Antifungal activity, Bark extract, Wood preservation, Tree bark.

\section{Bazı odun kabuk ekstraktları arasında karşılaştırma:}

\section{Anti-fungal aktivite olarak}

\section{Özet}

Çalışmanın amacı: Çevre dostu ve doğada çözünebilen odun koruma maddelerine olan ihtiyaç son yıllarda artmıştır. Bu çalışmada, ağaç kabuklarının antifungal etkileri incelenmiştir.

Çalışma alanı: Sahil çamı (Pinus pinaster L.), demir (Casuarina equisetifolia L.), mimoza (Acacia mollissima L.) kızılçam (Pinus brutia Ten.), ve göknar (Abies nordmanniana) ağaç kabukları kullanılmıştır.

Materyal ve Yöntem: TAPPI standardına göre alkol-benzen ekstraksiyonu sonucu elde edilen ekstrakların iki farklı konsantrasyonu hazırlanmıştır. Kabuk ekstraklarının etkinliği esmer çürüklük mantarı Coniophera puteana, ve beyaz çürüklük mantarı; Trametes versicolor'a karşı değerlendirilmiştir.

Sonuçlar: Sahil çamı ve göknar ağaç kabuk ekstraktları T. Versicolor mantarına karşı, C. puteana mantarından daha fazla dayanım göstermiştir. Bunun aksine demir ve mimoza ağaç kabuk ekstraktları esmer çürüklük mantarı C. puteana mantarına karşı daha dayanıklıdır. Mantar aktivitesinin engellenmesinde konsantrasyon en önemli faktördür. Mantar gelişiminin durdurulması konsantrasyona paralel bir şekilde artmıştır.

Araştırma vurguları: Doğal fenolik bileşikler bakımından zengin olan kabuk ekstraktlarının mantar aktivitesini engellediği düşünülmektedir. Ağaç kabuklarının odun koruma maddesi olarak kullanılabilme potansiyeline sahip olduğu görülmüştür.

Anahtar kelimeler: Antifungal aktivite, Kabuk ekstrakt1, Odun koruma maddesi, Ağaç kabuğu 


\section{Introduction}

Wood has been known as a renewable and natural material of biological origin since its primitive state. However, wood is the material that is degraded by biological hazards. Various microorganisms, such as fungi, mold, insect, and bacteria degrade the wood in its natural environment (Daniel et al., 2003). For this reason, the service life of the wood is extended by impregnating some preservatives (Özgenç and Yıldız, 2014). Certain wood preservatives in the markets have been removed or limited for some applications such as chromated copper arsenate (CCA), pentachlorophenol (PCP) due to containing toxic chemicals (EPA, 13.02.15; Mourant et al., 2005). New wood preservatives, modification and impregnation methods have been developed to ensure effective protection for wood industry. Markets for natural wood preservatives have been called environmentally friendly or chemical free alternatives to treated wood (Kirker et al., 2013). Moreover, preservatives containing organic substances could be easily disappeared in the nature (Onuorah, 2000). Considering all of this, natural bark extracts may be as alternatives for intended purposes in wood preservation industry. For this purpose, wood barks, fruits, seeds, heartwood of durable species have been investigated in recent years (Yang, 2009; Tascioglu et al., 2013; Kartal et al., 2006; Mohan et al., 2008).

The study of bark extracts as natural wood preservatives is wide-ranging in literature. Differences between softwood and hardwood have been found to regard to chemical and anatomical properties of the wood bark (Singh and Singh, 2012). Fradinho et al. (2002) showed that the extraction of maritime (Pinus pinaster L.) bark with aqueous alkaline solutions yields extracts which contain sugars, lignin and condensed tannins. Pine bark products including waxes, resins and phenolic extractives, have served as adhesive components. The wood treated with natural waxes extracted from pine bark shows hydrophobic properties (Singh and Singh, 2012). Tascioglu et al. $(2012,2013)$ indicated that mimosa and quebracho extracts could be utilized as an environmentally sound alternative wood preservative chemical for indoor applications. Significant antifungal effects were observed on the growth media treated with bark extracts of Carya ovata, Quercusrubra and Pinus strobus (Harun and Labosky, 1984). The bark extract of Delonix regia was found the maximum percentage inhibition of fungal mycelial growth against Penicillium selerotigenum (70.37\%) and Paecilomyces variotii (77.78\%) by Salem et al. (Salem et al., 2014).

The main objective of this study was to investigate the antifungal efficiency of four different tree bark extracts against woodrotting fungus. For this purpose maritime (Pinus pinaster L.), iron (Casuarina equisetifolia L.), mimosa (Acacia mollissima L.), and fir (Abies nordmanniana L.) tree barks were selected. This bark species were examined as organic biocide for an alternative wood protection material. To determine the effectiveness of bark extracts, brown-rot and white rot fungus; Coniophora puteana and Trametes versicolor, were selected respectively.

\section{Material and Method \\ Plant materials}

The barks were peeled off from the 20-30 year old maritime (Pinus pinaster L.), iron (Casuarina equisetifolia L.), mimosa (Acacia mollissima L.), and fir (Abies nordmanniana) trees that were cut down in Trabzon province in the north of Turkey. TAPPI T $257 \mathrm{~cm}-12$ and TAPPI T $264 \mathrm{~cm}-07$ standard methods were used for the preparation and chopping barks of mimosa, iron, maritime pine, and fir trees for extraction analysis. The dried barks were prepared by milling laboratory type Willey type mills for extraction. For extracting, 40 mesh sieves were used and the remaining 60 mesh sieves were used.

\section{Extracts preparations}

All tree barks were air-dried at room temperature and then ground by using a laboratory scale Willey mill to obtain 40 to 60-mesh wood powder. To obtain extractives, the bark powders were extracted in a Soxhlet extractor. The bark powder ( $25 \mathrm{~g}$ for each) was soaked in $300 \mathrm{~mL}$ of ethyl alcohol:benzene $(1: 2 \mathrm{v} / \mathrm{v})$. The solvents from each extracts were removed by using a rotary evaporator at $50{ }^{\circ} \mathrm{C}$ and stored in sealed flasks at $4^{\circ} \mathrm{C}$ until use. 


\section{Anti-fungal test}

The antifungal activity assay against the growth of Trametes versicolor, and Coniophera puteana, was performed following Salem et al. (2014). About $15 \mathrm{~mL}$ potato dextrose agar (PDA) medium containing the concentrated extract (1000, $2000 \mu \mathrm{L}$ ) was poured into each petri dish and allowed to solidify. A 1-cm disc of 7-day-old culture of tested fungi was placed at the center of the Petri dish and incubated at $26 \pm 2^{\circ} \mathrm{C}$ and $70 \pm 2 \%$ relative humidity for seven days. After incubation, the colony diameter was measured in centimeters. Three PDA medium for each fungi species was used as a control. The alcohol was also added in the PDA medium without extractives to investigate the alcohol effect on the fungus growth. It was observed that alcohol has no significant effect on fungal growth. The percentage inhibition of mycelial growth, in terms of fungi toxicity of the extracts, was calculated using the following formula,

\%inhibition $=[(M c-M t) / M c] \times 100$

Where $M c$ is the average increase in mycelial growth in control and $M t$ is the average increase in mycelial growth in treatment. The experiment was performed in six replicate for each bark extract.

\section{Results and Discussion}

The bioassay for anti-fungal activity was to evaluate the effecting of extractives against wood-rotting fungus; Coniophera puteana, and Trametes versicolor. The fungal grwoth on the wood extract/agar medium was seen in Fig 1-5. When compared to control samples (Fig. 5), wood bark extractives did not allow the growth of fungus, especially in high concentration. According to results, the inhibition index of wood bark extracts used in this study was more effective with white-rot fungi; T. versicolor than brown-rot fungi; $\mathrm{C}$. puteana at lower concentration $(1000 \mu \mathrm{L})$. However, effectiveness of extracts remained similar at high concentrations $(2000 \mu \mathrm{L})$ (Özgenç and Durmaz, 2015).

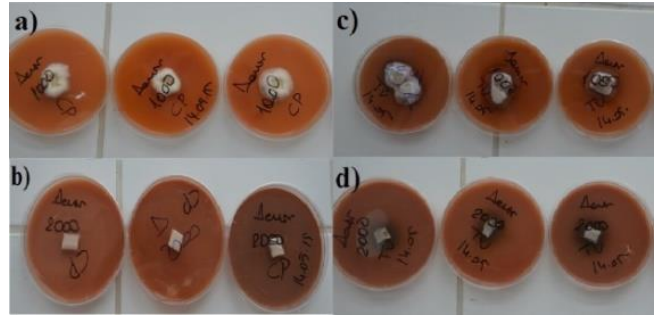

Figure 1. Iron tree bark extract against fungus; a) $1000 \mu \mathrm{L}$ against C.P., b) $2000 \mu \mathrm{L}$ against C.P., c) $1000 \mu \mathrm{L}$ against T.V., d) $2000 \mu \mathrm{L}$ against T.V.

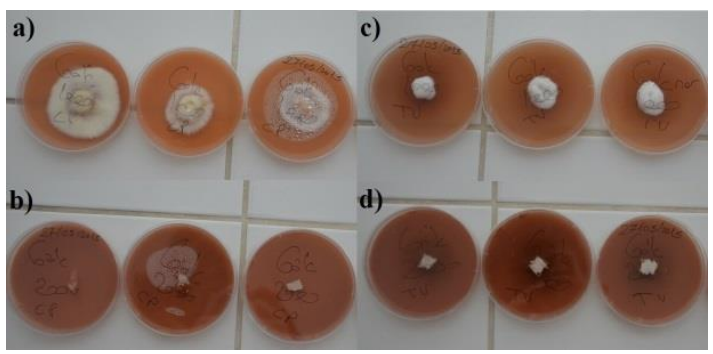

Figure 2. Fir tree bark extract against fungus; a) $1000 \mu \mathrm{L}$ against C.P., b) $2000 \mu \mathrm{L}$ against C.P., c) $1000 \mu \mathrm{L}$ against T.V., d) $2000 \mu \mathrm{L}$ against T.V.

The inhibition efficiency of bark extractives were also given in Table 1 and Table 2. The efficiency of extractives against wood-rot fungus is significant even in the low concentration of extractives $(1000 \mu \mathrm{L})$. However maximum inhibition was $88.89 \%$ and $86.91 \%$ at the highest concentration $(2000$ $\mu \mathrm{L})$ for $C$. puteana and $T$. versicolour, respectively. This indicates that the inhibition of fungal growth depended on the concentration of extractives as well as wood species.

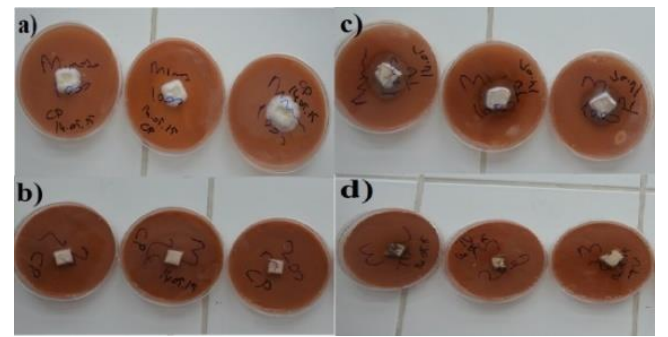

Figure 3. Mimosa tree bark extract against fungus; a) $1000 \mu \mathrm{L}$ against C.P., b) $2000 \mu \mathrm{L}$ against C.P. c) $1000 \mu \mathrm{L}$ against T.V. d) 2000 $\mu \mathrm{L}$ against $\mathrm{T}$. $\mathrm{V}$.

Variation in extractive content depends on the plant diversity. Numerous chemicals such as terpenoids, alkaloids, condensed tannins, 
and many others consist of extractives which are responsible for natural durability (Taylor et al., 2002). Hardwood species typically prone to be degraded by white rot fungus. On the contrary, softwood species are commonly nondurable against brown rot fungus (Panshin and DeZeeuw, 1980). Results showed that the bark extracts of hardwood species was more efficient against brown-rot fungi (Fig. 1,3); $C$. puteana than white-rot fungi; T. versicolor (Fig. 2, 4). When the hardwood species were compared in their own, extract from mimosa bark was more efficient against $C$. puteana, as seen in Fig. 3. Conversely, fir and maritime pine bark extract, which is a softwood species, showed more antifungal activity against $T$. versicolor, as seen in Fig 2, 4. However, the high concentration of extracts indicated the same efficiency against both of fungus.

Table 1. The inhibition efficiency of bark extract against wood-rot fungus $(1000 \mu \mathrm{L})$ (\%)

\begin{tabular}{lll}
\hline $\begin{array}{l}\text { Wood } \\
\text { species }\end{array}$ & $\begin{array}{l}\text { C. puteana } \\
\%\end{array}$ & $\begin{array}{l}\text { T. versicolor } \\
\%\end{array}$ \\
\hline Mimosa & 77.78 & 55.37 \\
& $(0.003)$ & $(0.004)$ \\
Iron & 68.61 & 58.38 \\
Maritime & $(0.001)$ & $(0.005)$ \\
pine & 55.78 & 74.54 \\
Fir & $(0.002)$ & $(0.003)$ \\
& 49.39 & 73.33 \\
\end{tabular}

Note: Values in parentheses are the standard deviations.

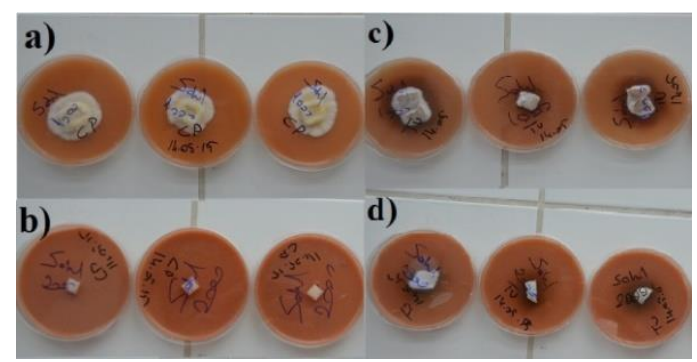

Figure 4. Maritime pine tree bark extract against fungus; a) $1000 \mu \mathrm{L}$ against C.P., b) $2000 \mu \mathrm{L}$ against C.P., c) $1000 \mu \mathrm{L}$ against T.V. d) $2000 \mu \mathrm{L}$ against T.V.

Table 2. The inhibition efficiency of bark extract against wood-rot fungus $(2000 \mu \mathrm{L})$ $(\%)$

\begin{tabular}{lll}
\hline $\begin{array}{l}\text { Wood } \\
\text { species }\end{array}$ & $\begin{array}{l}\text { C. puteana } \\
\%\end{array}$ & $\begin{array}{l}\text { T. versicolor } \\
\%\end{array}$ \\
\hline \multirow{2}{*}{ Mimosa } & 88.89 & 86.91 \\
& $(0.001)$ & $(0.002)$ \\
Iron & 88.89 & 86.91 \\
Maritime & $(0.001)$ & $(0.001)$ \\
pine & 88.89 & 86.91 \\
Fir & $(0.002)$ & $(0.001)$ \\
& 88.89 & 86.91 \\
& $(0.001)$ & $(0.002)$ \\
\hline
\end{tabular}

Note: Values in parentheses are the standard deviations.

Numerous plants contain organic compounds, which are responsible for producing of pharmaceuticals, insecticide, and fungicide (Satish et al., 2007). According to Hammurger and Hostettmann (1991), there would be over 400,000 plant chemicals and more than 10,000 of which associated with natural durability. For this purpose, there are diversity of studies on the plant based extract (Kartal et al., 2006; Maoz et al., 2007; Özgenç et al., 2016; Satish et al. 2007; Sing and Sing, 2012; Yang, 2009; Tascioglu et al., 2012; Tascioglu et al., 2013). However the most of wood species have never been investigated. Many plant chemicals, which could be effective against pesticide, have been remained to be evaluated.

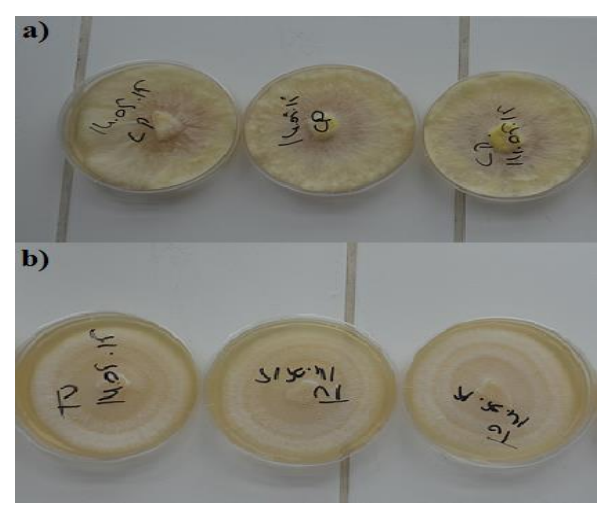

Figure 5. Control fungus without extractives; a) C. puteana, b) T. versicolor

\section{Conclusion}

In this study, antifungal effect of various wood bark extracts was investigated to elucidate their efficiency against white-rot fungi, and brown-rot fungi; Trametes versicolor, and Coniophera puteana, respectively. The bark extracts showed great 
antifungal activity against both of fungus. Results showed that the inhibition of fungal growth increased with increasing concentration of bark extracts. The efficient inhibition of fungal growth against both of fungus was obtained at high concentration $(2000 \mu \mathrm{L})$.

As a result of this study, bark extract inhibited fungal activity. While mimosa extract had an effective antifungal properties against $C$. puteana, maritime pine extract showed an efficient inhibition against $T$. versicolor. Moreover, maritime and fir bark extract showed a high inhibition against white rot fungi in a similar manner. These results suggested that wood bark extract have antifungal properties and could be potentially evaluated in the development of environmentally friendly wood preservatives.

\section{Acknowledgement}

The authors would like to thank Karadeniz Technical University, Research Fund (Project No: FHD-2015-5190), in Turkey provided for support. This study was presented at International Forestry Symposium on 03-06 October 2016, Kastamonu, Turkey.

\section{References}

Daniel G., Goodell B., Nicholas D. D., Schultz, T. P., (2003). Microview of wood under degradation by bacteria and fungi, ACS Symposium Series Wood Deterioration and Preservation, 34-72. ISBN : 0841237972

Fradinho D.M., Neto C.P., Evtuguin D., Jorge F.C., Irle M.A., Gil M.H., Jesus J.P. (2002). Chemical characterization of bark and of alkaline bark extracts from maritime pine grown in Portugal. Industrial Crops and Products, 16, 23-32. DOI:https://doi.org/10.1016/S09266690(0 2)00004-3.

Gao H., Shupe T.F., Eberhardt L., Hse C.Y. (2007). Antioxidant activity of extracts from the wood and bark of Port Orford cedar. J. Wood Sci, 53, 147-152. DOI: https://doi.org/10.1007/s10086-006-0850$\mathrm{Z}$

Hamburger M., Hostettmann K. (1991). Bioactivity in plants: The link between phytochemistry and medicine. Phytochemistry, 30, 3864-3874. DOI: https://doi.org/10.1007/s10086-006-0850$\mathrm{z}$.

Harun J., Labosky P. (1985). Antitermitic and antifungal properties of selected bark extractives. Wood and Fiber Science, 17 (3), 327-335. URL: https://wfs.swst.org/index.php/wfs/article/ view/2099/2099

Jiang G.G., Fang G.Z, Li L.L., Shi Z.X., Zhang Z.R. (2014). Study on antioxidant activity of catalyzed hydrogen degradation product of polymeric proanthocyanidins (LPPC) from Larixgmelinii bark. BioResources, 9 (1), 662-672. DOI: 10.15376/biores.9.1.662-672

Kartal S.N., Hwang W.J., Imamura Y., Sekine Y. (2006). Effect of essential oil compounds and plant extracts on decay and termite resistance of wood. Holz als Roh- und Werkstoff, 64 (6), 61-455. DOI: https://doi.org/10.1007/s00107-006-00988

Kirker G.T., Blodgett A.B., Arango R.A., Lebow P.K., Clausen C.A. (2013). The role of extractives in naturally durable wood species. International Biodeterioration and Biodegradation, 82, 53-58.

DOI: https://doi.org/10.1016/j.ibiod.2013.03.00 7

Kocaefe D., Saha S. (2012). Comparison of the protection effectiveness of acrylic polyurethane coatings containing bark extracts on three heat-treated North American wood species: Surface degradation. Applied Surface Science, 258, 5283-5290.

DOI: https://doi.org/10.1016/j.ibiod.2013.03.00 7

Maoz M., Weitz I., Blumenfeil M., Freitag C., Morrell J.J. (2007). Antifungal activity of plant derived extracts against G. trabeum. Proceedings IRG Annual Meeting, IRG/WP 07-30433, Stockholm, Sweden. URL: $\quad$ http://www.irgwp.com/irgdocs/details.php?b21d9b962c13-4a74-8999-a7aaa6bf8a35

Mohan D., Shi J., Nicholas D.D., Pittman C.U., Steele PH., Cooper J.E. (2008). Fungicidal values of bio-oils and their lignin-rich fractions obtained from wood/bark fast pyrolysis. Chemosphere, $71 \quad$ (3), 65-456. DOI: 
https://doi.org/10.1016/j.chemosphere.200 7.10.049

Mourant D., Yang D.Q., Lu X., Roy C. (2005). Anti-fungal properties of the pyroligneus liquors from the pyrolysis of softwood bark. Wood Fiber and Technology, 37 (3), 542-548. URL: https://wfs.swst.org/index.php/wfs/article/ view/1028

Onuorah E.O. 2000. The wood preservative potentials of heartwood extracts of Milicia excelsa and Erythrophleum suaveolens. Bioresource Technology, 75 (2), 3-171. DOI:

http://www.sciencedirect.com/science/arti cle/pii/S0960852499001650

Ozgenc O., Yildiz U.C. (2014). Surface Characteristics of Wood Treated with New Generation Preservatives after Artificial Weathering, Wood Research, 59,(3),605616.URL:http://www.centrum dp.sk/wr/201404/08.pdf

Özgenç Ö., Durmaz S., Kuştaş S., Erişir E. (2016). The determination of antifungal specialties on some tree bark extracts. Journal of Advanced Technology Sciences, 5 (1), 147-152. ISSN:2147-3455

Özgenç Ö., Durmaz S., (2016). Anti-Fungal Activity on Some Wood extracts as a Wood Protectant, 47th IRG Annual Meeting, Lisbon, Portugal, IRG/WP 1630684.

Panshin A.J., DeZeeuw C. 1980. Textbook of wood technology, 722 s, McGraw-Hill, Inc., New York. ISBN: 0070484414

Saha S., Kocaefe D., Boluk Y., Pichette A. (2011). Enhancing exterior durability of jack pine by photo-stabilization of acrylic polyurethane coating using bark extract. Part 1: Effect of UV on color change and ATR-FT-IR analysis. Progress in Organic Coatings, $\quad 70, \quad 376-382 . \quad$ DOI: https://doi.org/10.1016/j.porgcoat.2010.09 .034

Salem M., Abdel-Megeed A., Ali H.M. (2014). Stem wood and bark extracts of Delonixregia (Boj. Ex. Hook): Chemical analysis and antibacterial, antifungal, and antioxidant properties. BioResources, 9 (2), 2382-2395.

DOI: 10.15376/biores.9.2.2382-2395

Satish S., Mohana D.C., Ranhavendra M.P., Raveesha K.A. (2007). Antifungal activity of some plant extracts against important seed borne pathogens of Aspergillus sp. An International Journal of Agricultural Technology, 3 (1), 109-119.

URL:http://www.ijat-aatsea.com/past_v3 n1.html

Singh T., Singh A.P. (2012). A review on natural products as wood protectant. Wood Sci. Technol, 46, 851-870. DOI: https://doi.org/10.1007/s00226-011-04485

Tascioglu C., Yalcin M., Sen S., Akcay C., (2013). Antifungal properties of some plant extracts used as wood preservatives. International Biodeterioration and Biodegradation, 85, 23-28. DOI: https://doi.org/10.1016/j.ibiod.2013.06.00 4

Tascioglu C., Yalcin M., Troya T., Sivrikaya H., (2012). Termiticidal properties of some wood and bark extracts used as wood preservatives. BioResources, 7 (3), 29602969. DOI: 10.15376/biores.7.3.29602969

Taylor A.M., Gartner, B.L., Morrell, J.J. (2002). Heartwood formation and natural durability: A review. Wood and Fibre Science, 34 (4), 587-611. URL: https://wfs.swst.org/index.php/wfs/article/ view/539

Vázquez G., Fontenla E., Santos J., Freire M.S., González-Álvarez J., Antorrena G. (2008). Antioxidant activity and phenolic content of chestnut (Castanea sativa) shell and eucalyptus (Eucalyptus globulus) bark extracts. Industrial Crops and Products, 28, 279-285. DOI: https://doi.org/10.1016/j.indcrop.2008.03. 003

Vázquez G., González-Álvarez J., Santos J., Freire M.S., Antorrena G. (2009). Evaluation of potential applications for chestnut (Castanea sativa) shell and eucalyptus (Eucalyptus globulus) bark extracts. Industrial Crops and Products, 29, 364-370. DOI: https://doi.org/10.1016/j.indcrop.2008.07. 004

Yang D. Q. (2009). Potential utilization of plant and fungal extracts for wood protection. Forest Prod J., 59 (4), 97-103. URL:https://search.proquest.com/openvie 
w/19d15548d267d33ce1a467ad9e7e5a09/ 1 ?pq-origsite $=$ gscholar $\& \mathrm{cbl}=25222$

Wang S.Y., Wu J.H., Cheng S.S., Lo C.P., Chang H.N., Shyur L.F., Chang S.T. (2004). Antioxidant activity of extracts from Calocedrusformosana leaf, bark, and heartwood. J. Wood Sci., 50, 422-426. Retrieved 13.02.2015, from URL-1: http://www.epa.gov/oppad001/reregistrati on/cca/alternativestocca.htm. 